\title{
The Sublethal Effects of a Systemic Insecticide on the Vine Mealybug Parasitoids Anagyrus sp. near pseudococci (Girault) and Coccidoxenoides perminutus (Timberlake) (Hymenoptera: Encyrtidae)
}

N. Mgocheki1 ${ }^{1,2}$, P. Addison $^{1 *}$

(1) Department of Conservation Ecology and Entomology, Faculty of AgriSciences, Stellenbosch University, Private Bag X1, Matieland 7602, South Africa.

(2) Crop Science Department, Faculty of Agriculture and Environmental Sciences, Bindura University of Science Education, P/Bag 1020, Bindura, Zimbabwe. E-mail address: nmogocheki@yahoo.com.

Submitted for publication: December 2014

Accepted for publication: December 2014

Key words: Imidacloprid, neonicotinoid, Planococcus ficus, vineyards, integrated pest management, biological control, parasitoids

Imidacloprid is a systemic insecticide used for the control of the vine mealybug Planococcus ficus. However, biological control of $P$. ficus is the primary alternate management method recommended for the integrated control of this pest. We therefore aimed to establish the detrimental effects on the development of Anagyrus. sp. near pseudococci and Coccidoxenoides perminutus feeding on imidacloprid-contaminated vine mealybugs as indicated by the subsequent emergence and survival of the $F_{1}$ generation. The results imply that $A$. sp. near pseudococci and $C$. perminutus were equally susceptible to imidacloprid, based on probit analysis. However, survival was significantly different between the control and insecticide treatment for $C$. perminutus $\left(\chi^{2}=23.80\right.$; d.f. $\left.=3 ; \mathrm{p}<0.001\right)$, but not for $A$. sp. near pseudococci $\left(\chi^{2}=5.07\right.$; d.f. $=3$; $p$ $=0.17$ ). As this study was laboratory based, the effect of imidacloprid on populations of parasitoids in the field should be assessed further. Treatment recommendations to minimise the impact on parasitoids are discussed briefly.

\section{INTRODUCTION}

The vine mealybug Planococcus ficus (Signoret) (Hemiptera: Sternorrhyncha: Pseudococcidae) is a major pest in vineyards worldwide (Ben-Dov, 1994). One of the primary methods used for its control in vineyards is augmentative releases of parasitic wasps, namely Coccidoxenoides perminutus (Timberlake) and Anagyrus sp. near pseudococcidae (Walton et al., 2012). However, the application of synthetic insecticides can hamper biological control efforts, whereby insecticides were shown to have significant acute toxic effects on $C$. perminutus and $A$. sp near pseudococci, as opposed to fungicides commonly applied in South African vineyards (Walton \& Pringle 1999; Mgocheki \& Addison, 2009). Imidacloprid is a systemic insecticide that has soil, foliar and seed uses for the control of sap-sucking pests such as aphids, thrips, whiteflies and mealybugs (Ahmed et al., 2001; Widiarta et al., 2001; Pringle, 1998). In vineyards it is applied as a soil drench against vine mealybugs at budburst to pea berry size, and then 21 to 45 days after first application if a split application is required (Anonymous, 2007). Imidacloprid belongs to the chloronicotinyl class of insecticides that act on the nervous system, causing a blockage of the post-synaptic acetyl cholinesterase receptors (Buckingham et al., 1997; Mukherjee \& Gopal, 2000). Soil applied imidacloprid is taken up by roots and is translocated acropetally within the xylem (Sur \& Stork, 2003) and provides high persistence in vines (Byrne \& Toscano, 2006). The harmful effects of imidacloprid on natural enemies have been documented widely, e.g. for predatory mites in table grape vineyards (James \& Price, 2004), for parasitoids and predators of P. ficus (Krischik et al., 2007; Cloyd \& Dickinson, 2006), and for lacewings feeding on flowers in greenhouses (Rogers et al., 2007)survival of adult green lacewing, Chrysoperla carnea Stephens (Neuroptera: Chrysopidae

Unlike the non-systemic insecticides (see Mgocheki \& Addison, 2009), many systemic insecticides as well as their metabolites are regarded as 'safe' for natural enemies and other beneficial insects, like bees, although mortality may occur depending on the insecticide's persistence (Ozawa et al., 1998; Stapel et al., 2000). Most bioassays have focused on acute toxicity resulting from parasitoids coming into contact with pesticide residues or sublethal effects resulting in altered host searching or foraging ability, fecundity and

*Corresponding author: E-mail address: pia@sun.ac.za

Acknowledgements: We are grateful to Dr K.L. Pringle for assistance with the probit analysis. This work is based on research supported by the National Research Foundation of South Africa (Grant specific unique reference number (UID) 71909), the South African Table Grape Association and Winetech 
male:female ratio (Desneux et al., 2007). Juvenile stages of parasitoids are subjected to systemic insecticides when they develop in hosts that have fed on treated plants. Such hosts will have fed off plants with weathered pesticide that is not sufficient to cause death in the host or have developed resistance to the systemic pesticide (Stapel et al., 2000; Desneux et al., 2007).

Imidacloprid SC $350 \mathrm{~g} / \mathrm{L}$ is considered a mediumrisk insecticide for use in vineyards utilising integrated production of wine (IPW) principles (Anonymous, 2000), which seek to limit unnecessary pesticide applications and ensure sustainable wine grape production in South Africa. The inclusion of biological control in an integrated pest management approach against $P$. ficus is highly encouraged, so it therefore is important to identify the risks that imidacloprid presents to vine mealybug parasitoids foraging in treated vineyards. This investigation therefore aimed to establish the detrimental effects on the development of $A$. sp. near pseudococci and $C$. perminutus feeding on imidacloprid-contaminated vine mealybugs, as indicated by the subsequent emergence and survival of the $F_{l}$ generation. This information is critical for updating the IPW guidelines to ensure that the most efficient and sustainable integrated pest management (IPM) methods are used against $P$. ficus.

\section{MATERIALS AND METHODS}

Using Confidor 350SC, or $350 \mathrm{~g} / \mathrm{l}$ pure active ingredient (Bayer Crop Science, Paarl, South Africa), a stock solution of the highest dose (12 ml imidacloprid/1 $000 \mathrm{ml}$ water for the pot experiment, $=$ four times field recommended rate) was prepared and serial dilutions were made with distilled water to give double, field, $1 / 2$ and $1 / 4$ recommended rates. Potted vines were established in the laboratory under ambient conditions in the dormant stage. The experiments were initiated just before bud break. Vines were pre-watered at least one hour before application of the insecticide to ensure adequate wetting. Then $166 \mathrm{ml}$ of imidacloprid was applied as a soil drench around the base of each of five potted vines for all application rates. A blank treatment with no imidacloprid (water control) was included as a sixth treatment and the experiment was replicated five times. The pesticide was allowed to translocate for 48 hours and then $150 \mathrm{ml}$ of clean water was applied to each vine to wash the imidacloprid into the soil. Thereafter the vines were irrigated with the same amount of water every three days until 21 days after treatment. Vines were infested with $1001^{\text {st }}$ and $2^{\text {nd }}$ instar P. ficus (for C. perminutus bioassays) and $1003^{\text {rd }}$ instar to pre-ovipositing female $P$. ficus (for $A$. sp. near pseudococci bioassays). Anagyrus sp. was field collected from $P$. ficus and incubated in the laboratory at room temperature until emergence. Colonies were maintained in the laboratory on 3rd instar to adult vine mealybugs feeding on butternut squash (Islam \& Copland, 1997). Coccidoxenoides perminutus were sourced from DuRoi IPM (Letsitele, South Africa) as mature pupae. Newly emerged individuals were allowed to feed for $24 \mathrm{~h}$ on a honey water solution (50:50), after which they were used in the experiments. The vines were covered in clear muslin cloth and mealybugs were allowed to feed for two days. Parasitoids $(n=20)$ were then released onto the vines with mealybugs for 24 hours, after which they were removed. Mealybugs were allowed to feed on the vines for a further 48 hours, after which they were kept in vials at $26 \pm 0.5^{\circ} \mathrm{C}, 65 \pm 5 \% \mathrm{RH}$ and a $12: 12$ (L:D) photoperiod. They were inspected daily between 12:00 and 15:00 hours for any emerged parasitoids. When no more parasitoids emerged, the percentage of emerged parasitoids was calculated.

The emerged parasitoids were allowed to reproduce on mealybugs feeding from the same treated vines (but with weathered pesticide) and their offspring ( $F_{1}$ generation) were examined for longevity over 21 days $(A$. sp. near pseudococci) and seven days (C. perminutus), based on adult survival rates (Ceballo \& Walter, 2005; Suma et al. 2012). A. sp. near pseudococci females were mated, while the parthenogenetic $C$. perminutus were not.

\section{Data analysis}

The bioassay data for each parasitoid species were pooled for each treatment replicate to obtain homogeneity before Probit analysis (Polo-PC LeOra Software, 1987) after correction for control mortality using Abbott's formula (Abbott, 1925). Repeated measures ANOVA, followed by Tukey's HSD test, were performed to compare differences in emergence rate (or mortality as shown by the percentage of un-emerged parasitoids) of the two parasitoid species. Longevity of the $F_{1}$ generation females was analysed using the KaplanMeier (product limit) survival analysis in Statistica 12 (StatSoft Inc., 2012). .

\section{RESULTS}

Probit regression showed that fiducial limits for the two parasitoids overlapped (Table 1) and therefore mortality did not differ significantly between the two parasitoid species (Robertson et al., 2007). As expected, both $A$. sp. near pseudococci and $C$. perminutus failed to emerge at high doses of imidacloprid. The probit regression line intercepts and slopes (Table 1) for both A. sp. near pseudococci and $C$. perminutus did not differ significantly, and therefore the hypothesis of equality of regression lines was accepted $\left(\chi_{\mathrm{df}=2}^{2}\right.$ $=5.78 ; \mathrm{p}=0.055)$, as well as that of parallelism $\left(\chi_{\mathrm{df}=1}^{2}=\right.$ $0.19 ; \mathrm{p}=0.664)$. This implies that $A$. sp. near pseudococci and $C$. perminutus are similar in their susceptibility to

TABLE 1. Probit parameters of dose responses of Anagyrus sp. near pseudococci and Coccidoxenoides perminutus parasitising the vine mealybug, Planococcus ficus, feeding on imidacloprid SC (350 g/L) treated vines.

\begin{tabular}{lllllll}
\hline Parasitoid & $\begin{array}{l}\mathrm{LC}_{50} \\
(\mathrm{ml} / \mathrm{L})\end{array}$ & $\begin{array}{l}95 \% \\
\text { fiducial limits }\end{array}$ & $\begin{array}{l}\mathrm{LC}_{90} \\
(\mathrm{ml} / \mathrm{L})\end{array}$ & $\begin{array}{l}95 \% \\
\text { fiducial limits }\end{array}$ & $\begin{array}{l}\text { Intercept* } \\
\text { ( } \pm \text { std. err. })\end{array}$ & $\begin{array}{l}\text { Slope* } \\
( \pm \text { std. err. })\end{array}$ \\
\hline A. sp. near pseudococci & 1.1198 & 0.57 to 1.67 & 11.3572 & 7.21 to 25.76 & 4.7961 & 1.2272 \\
C. perminutus & 1.7608 & 0.49 to 3.33 & 23.1282 & 8.95 to 891.5 & $(0.8578)$ & $(0.1449)$ \\
\hline
\end{tabular}

*Common intercept and slope. 
imidacloprid (Fig. 1).

The cumulative proportion surviving, i.e. the cumulative proportion of the $F_{1}$ generation of $A$. sp. near pseudococci and $C$. perminutus surviving up to 21 and seven days respectively, is shown in Fig. 2 (C. perminutus) and Fig. 3 (A. sp. near pseudococci). The survival function of $A$. sp. near pseudococci drops off sharply in the first eight days, and thereafter declines steadily until 17 days. Survival was significantly different between the control and insecticide treatment for $C$. perminutus $\left(\chi^{2}=23.80\right.$; d.f. $\left.=3 ; \mathrm{p}<0.001\right)$, but not for $A$. sp. near pseudococci $\left(\chi^{2}=5.06\right.$; d.f. $=3$; $\mathrm{p}=0.168)$. Survival could not be compared directly between the two parasitoid species because of natural differences in lifespan.

\section{DISCUSSION}

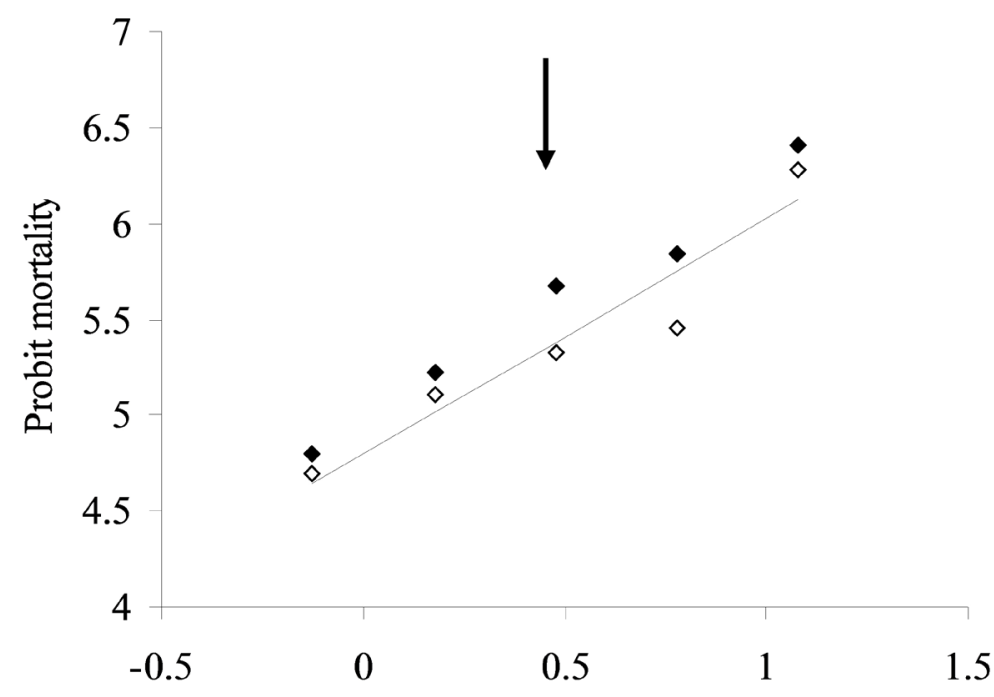

Log dose

FIGURE 1

Probit mortality (inability to emerge) of Anagyrus sp. near pseudococci $(\diamond)$ and Coccidoxenoides perminutus $(\diamond)$ to various doses of imidacloprid SC (350 g/L), using Planococcus ficus feeding on treated vines. Arrow indicates field dose rate (3 ml/L).

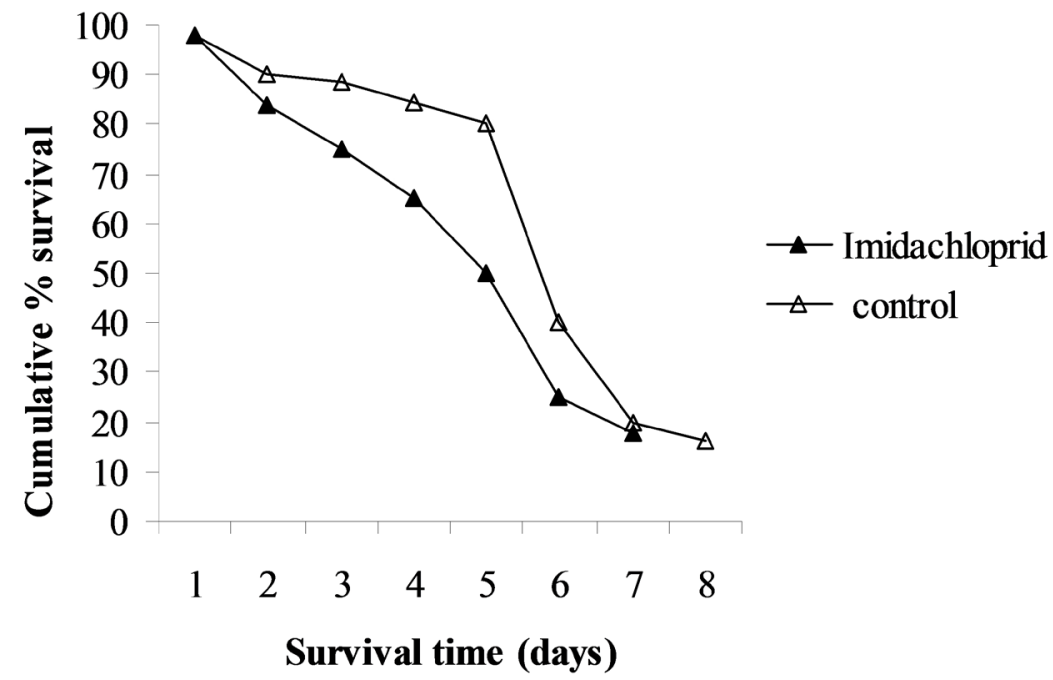

FIGURE 2

Survival function of Coccidoxenoides permunitus $F_{1}$ generation females that emerged from imidacloprid-contaminated Planococcus ficus individuals. 


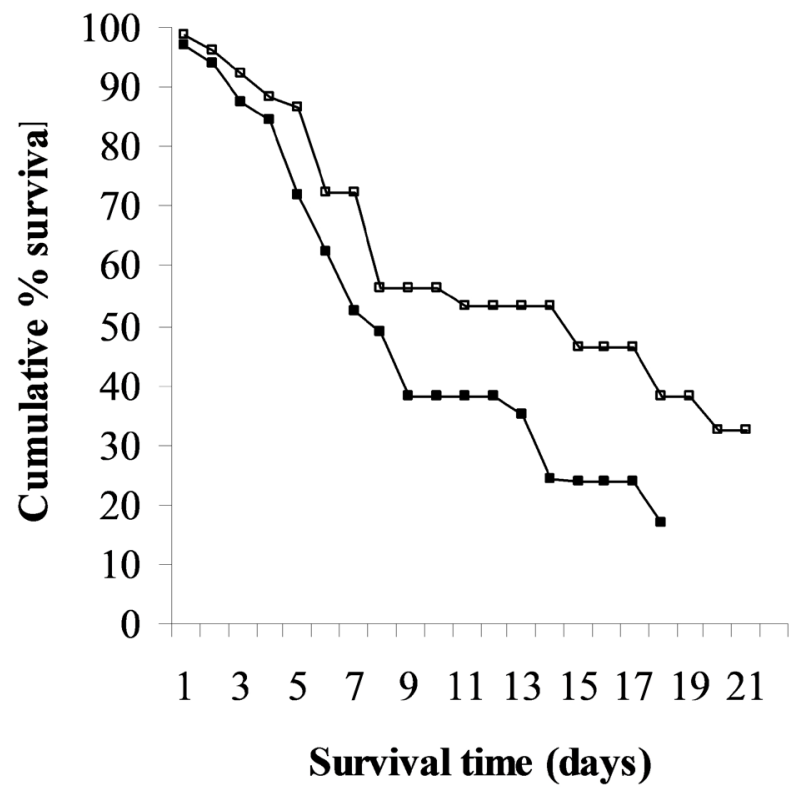

$\rightarrow$ Imidachloprid

$\rightarrow$ Control

FIGURE 3

Survival function of Anagyrus sp. near pseudococcus $F_{l}$ generation that emerged from imidacloprid-contaminated Planococcus ficus individuals.

vine mealybugs, their development and longevity are indeed affected negatively, with failure to emerge at higher doses. At low doses ( $1 / 4$ and $1 / 2$ and full recommended field rate), some parasitoids managed to emerge, but the longevity of the $F_{1}$ generation was significantly reduced for $C$. perminutus. Stapel et al. (2000) also reported reduced longevity of the parasitoid Microplitis croceipes Cresson (Hymenoptera: Braconidae) after feeding on extra floral nectar from cotton treated with soil-applied imidacloprid. Imidacloprid significantly reduced the survival of $C$. perminutus, while the survival of the $F_{l}$ generation of $A$. sp. near pseudococci was affected less. Coccidoxenoides perminutus is comparably smaller than $A$. sp near pseudococci, rendering it more susceptible to pre-imaginal sublethal effects of imidacloprid (Sohrabi et al., 2012).

Soil-applied imidacloprid is persistent and can continue to kill pests for more than 30 days (Widiarta et al., 2001). Therefore, soil-applied imidacloprid is particularly detrimental to C. perminutus, as this parasitoid species should be released early in the growing season, when temperatures are cooler, to effectively discourage build-up of high mealybug populations (Walton \& Pringle, 2005), while $A$. sp. near pseudococci is ideally adapted for hotter temperatures later in the season (Wohlfarter \& Addison, 2014). Alternate products are available that are not detrimental to parasitoids, in particular $A$. sp. near pseudococci parasitising P. ficus, including insecticidal soaps (e.g. Prev-Am ${ }^{\circledR}$ ) and tetramic acid insecticides (Mansour et al., 2011).

\section{CONCLUSIONS}

This study has indicated that C. perminutus and $A$. sp. near pseudococci are equally susceptible to imidacloprid systemic residues, as shown by the emergence rate and/or mortality of the $F 1$ generation. However, the progeny of imidaclopridcontaminated $A$. sp. near pseudococci and C. perminutus could still survive long enough to have an impact on mealybugs. This investigation did not establish the impact of this insecticide on important physiological activities like oviposition, searching ability and host recognition (Ruberson et al., 1998). It should also be noted that we did not assess whether there were any differences in mealybug acceptance of imidacloprid vines treated at different concentrations, as this was beyond the scope of this trial. Split applications could be substituted by one imidacloprid treatment at budburst to pea berry size, followed by the release of parasitoids about 45 days after treatment. Since this investigation was laboratory based, it is expected that imidacloprid could be more harmful under field conditions, as it works synergistically with other agrochemicals (e.g. Koppenhöfer et al., 2000; Van Dijk et al., 2013; Rondeau et al., 2014). This therefore should be investigated in a field-based trial.

\section{LITERATURE CITED}

Abbott, W.S., 1925. A method of computing the effectiveness of an insecticide. J. Econ. Entomol. 18, 265-267.

Ahmed, N.E., Kanan, H.O., Sugimoto, Y., Ma, Y.Q. \& Inanaga, S., 2001. Effect of imidacloprid on incidence of tomato yellow leaf virus. Plant Dis. $85,84-87$

Anonymous, 2000. South African guidelines for integrated production of wine [Promulgated under the Act on Liquor Products (Act 60 of 1989)]. Compiled by ARC Infruitec-Nietvoorbij, Fruit, Vine and Wine Institute of the Agricultural Research Council, Private Bag X5013, Stellenbosch 7599, South Africa. http://www.ipw.co.za (Accessed 7 August 2014).

Anonymous, 2007. A guide for the control of plant pests. Directorate: Food Safety and Quality Assurance; Subdirectorate: Agricultural Production Inputs. 40th Ed. Department of Agriculture, Republic of South Africa Government Printer, Pretoria. 
Ben-Dov, Y., 1994. A systematic catalogue of the mealybugs of the world (Insecta: Homoptera: Coccoidea: Pseudococcidae and Putoidae) with data on geographical distribution, host plants, biology and economic importance. Intercept Limited, Andover, U.K. 686pp.

Buckingham, S.D., Lapied, B., Le Corronc, H., Grolleau, F. \& Sattelle, D.B., 1997. Imidacloprid actions on insect neuronal acetylcholine receptors. J. Exp. Biol. 200, 2685-2692.

Byrne, F.J. \& Toscano, N.C., 2006. Uptake and persistence of imidacloprid in grapevines treated by chemigation. Crop Prot. 25, 831-834.

Ceballo, F.A. \& Walter, G.H., 2005. Why is Coccidoxenoides perminutus, a mealybug parasitoid, ineffective as a biocontrol agent - Inaccurate measures of parasitism or low adult survival? Biol. Control 33, 260-268.

Cloyd, R.A. \& Dickinson, A., 2006. Effect of insecticides on mealybug destroyer (Coleoptera: Coccinellidae) and parasitoid Leptomastix dactylopii (Hymenoptera: Encyrtidae), natural enemies of citrus mealybug (Homoptera: Pseudococcidae). J. Econ. Entomol. 99, 1596-1604.

Desneux, N., Decourtye, A. \& Delpeuch, J.M., 2007. The sublethal effects of pesticides on beneficial arthropods. Annu. Rev. Entomol. 52, 81-106.

Islam, K.S. \& Copland, M.J.W., 1997. Host preference and progeny sex ratio in a solitary koinobiont mealybug endoparasitoids, Anagyrus pseudococci (Girault) in response to its host stage. Biocontrol Sci. Techn. 7, 449-456.

James, D.G. \& Price, T.S., 2004. Field-testing of methyl salycilate for recruitment and retention of beneficial insects in grapes and hops. J. Chem. Ecol. 30, 1613-1628.

Koppenhöfer, A.M, Grewal, P.S. \& Kaya, H.K., 2000. Synergism of imidacloprid and entomopathogenic nematodes against whitegrubs: The mechanism, Entomologia Experimentalis et Applicata 94, 283-293.

Krischik, V.A., Landmark, A.L. \& Heimpel, G.E., 2007. Soil-applied imidacloprid is translocated to nectar and kills nectar-feeding Anagyrus pseudococci (Girault) (Hymenoptera: Encyrtidae). Environ. Entomol. 36, 1238-1245

Mansour, R., Suma, P., Mazzeo, G., Grissa Lebdi, K. \& Russo, A., 2011. Evaluating the side effects of newer insecticides on the vine mealybug parasitoid Anagyrus sp. near. pseudococci, with implications for integrated pest management in vineyards. Phytoparasitica 39, 369-376.

Mgocheki, N. \& Addison, P., 2009. Effect of contact pesticides on vine mealybug parasitoids, Anagyrus sp. near pseudococci (Girault) and Coccidoxenoides perminutus (Timberlake) (Hymenoptera: Encyrtidae). S. Afr. J. Enol. Vitic. 30, 110-116.

Mukherjee, I. \& Gopal, M., 2000. Environmental behaviour and translocation of imidacloprid in eggplant cabbage and mustard. Pest Manag. Sci. 56, 932-936.

Ozawa, A., Scuto, T. \& Ikeda, F., 1998. Effects of pesticides on Diglipus isaea (Walker) and Dacnusa sibirica (Tenlenga), parasitoids of Liriomyza trifolii (Burgess). Jpn. J. Appl. Entomol. 42, 149-161 (English Summary).

Preetha, G., Monoharan, T., Stanley, J. \& Kuttalam, S., 2010. Impact of chloronicotinyl insecticide imidacloprid, on egg, egg larval and larval parasitoids under laboratory conditions. J. Plant. Prot. Res. 50, 535-540.

Pringle, K.L., 1998. The use of imidacloprid as a soil treatment for the control of Eriosoma lanigerum (Hausmann) (Hemiptera: Aphididae). J. S. Afr. Soc. Hort. Sci. 8, 55-56.
Robertson, J.L., Preisler, H.K., Russell, R.M. \& Savin, N.E., 2007 (2nd ed). Bioassays with arthropods. CRC Press Taylor and Francis Group, London, New York.

Rogers, M.A., Krischik, V.A. \& Martin, L.A., 2007. Effect of soil application of imidacloprid on survival of adult green lacewing, Chrysoperla carnea (Neuroptera: Chrysopidae), used for biological control in greenhouse. Biol. Control 42, 172-177.

Rondeau, G., Sanchez-Bayo, F., Decourtye, A., Ramirez-Romero, R. \& Desneux, N., 2014. Delayed and time-cumulative toxicity of imidacloprid in bees, ants and termites. Scientific Reports 4, article number 5566, doi: $10.1038 /$ srep05566.

Ruberson, J.R., Nemoto, H. \& Hirose, Y., 1998. Pesticides and conservation of natural enemies in pest management. In: Barbosa, T. (ed). Conservation biological control. Academic Press, New York. pp 207 - 220.

Sohrabi, F., Shishehbor, P., Saber, M., \& Mosaddegh, M.S., 2012. Lethal and sublethal effects of buprofezin and imidacloprid on whitefly parasitoid Encarsia inaron (Hymenoptera: Aphenilidae), Crop Protection 32, 83-93.

Stapel, J.O., Cortesero, A.M. \& Lewis, W.J., 2000. Disruptive sublethal effects on biological control: Altered foraging ability and life span of a parasitoid after feeding on extrafloral nectar of cotton treated with systemic insecticides. Biol. Control. 17, 243-249.

StatSoft Inc., 2012. Statistica for Windows (Computer program). StatSoft Inc., Tulsa, OK.

Suma, P., Mansour, R., La Torre, I., Ali Bugila, A.A., Mendel, Z. \& Franco, J.C., 2012. Developmental time, longevity, reproductive capacity and sex ratio of the mealybug parasitoid Anagyrus sp. nr. Pseudococci (Girault) (Hymenoptera: Encyrtidae). Biocontrol. Sci. Techn. 22, 737-745.

Sur, R. \& Stork, A., 2003. Uptake, translocation and metabolism of imidacloprid in plants. Bull. Insect. 56, 35-40

Tennekes, H.A. \& Sanchez-Bayo, F., 2011. Time-dependent toxicity of neonicotinoids and other toxicants: Implications for a new approach to risk assessment. J. Environ. Anal. Toxicology S4, S4-001.

Van Dijk, T.C., Van Staalduinen, M.A. \& Van der Sluijs, J.P., 2013. Macroinvertebrate decline in surface water polluted with imidacloprid. PLoS ONE 8, e62374. doi:10.1371/journal.pone.006237

Walton, V.M. \&. Pringle, K.L., 1999. Effects of pesticides used on table grapes on the mealybug parasitoid Coccidoxenoides peregrinus. S. Afr. J. Enol. Vitic. 20, 31-34.

Walton, V.M. \& Pringle, K.L., 2005. Developmental biology of vine mealybug, Planococcus ficus (Signoret) (Homoptera: Pseudococcidae), and its parasitoid Coccidoxenoides perminutus (Timberlake) (Hymenoptera: Encyrtidae). African Entomol. 13, 143-147.

Walton, V.M., Daane, K.M. \& Addison, P., 2012. Principles of biological control in vineyards. In Bonstanian, N.J., Vincent, C. \& Isaacs, R. (eds.) Arthropod Management in Vineyards: Pests, Approaches, and Future Directions, Springer Dordrecht, Netherlands, pp 91-118.

Widiarta, N., Matsumura, M., Suzuki, Y. \& Nakasuji, F., 2001. Effects of sublethal doses of imidacloprid on the fecundity of green leafhoppers, Nephotettix spp. (Hemiptera: Cicadellidae) and their natural enemies. Appl. Entomol. Zool. 36, 501-507.

Wohlfarter, M. \& Addison, P., 2014. Life table study of Anagyrus sp. nr. pseudococci (Girault) (Hymenoptera: Encyrtidae) on its host, Planococcus ficus (Signoret) (Hemiptera: Pseudococcidae). African Entomol. 22, 250256. 